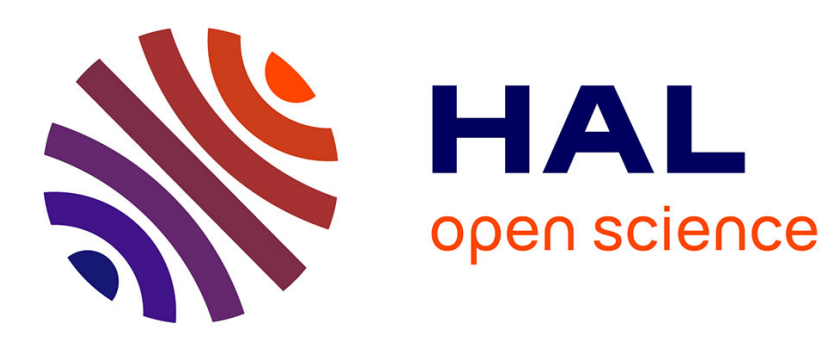

\title{
Illustrating the value of Open Access for text mining
}

\author{
Sylvain Massip, Charles Letaillieur
}

\section{To cite this version:}

Sylvain Massip, Charles Letaillieur. Illustrating the value of Open Access for text mining. ELPUB 2019 23rd edition of the International Conference on Electronic Publishing, Jun 2019, Marseille, France. , 10.4000/proceedings.elpub.2019.4 . hal-02175162

\section{HAL Id: hal-02175162 \\ https://hal.science/hal-02175162}

Submitted on 5 Jul 2019

HAL is a multi-disciplinary open access archive for the deposit and dissemination of scientific research documents, whether they are published or not. The documents may come from teaching and research institutions in France or abroad, or from public or private research centers.
L'archive ouverte pluridisciplinaire HAL, est destinée au dépôt et à la diffusion de documents scientifiques de niveau recherche, publiés ou non, émanant des établissements d'enseignement et de recherche français ou étrangers, des laboratoires publics ou privés. 


\section{OpSciDia}

The value of knowledge

\section{Illustrating the value of Open Access for}

text mining

Sylvain Massip and Charles Letaillieur

\section{Open Access - a growing opportunity}

- There are many arguments in favour of Open Access to scholarly publication in particular allowing a better appropriation of research by practitioners and interested citizens.

- In 2018, Open Access represented about $\mathbf{2 8 \%}$ of total published scientific articles ${ }^{1}$

- While the cost of publication is widely studied ${ }^{2}$, there are not many reports on the value that open access to scholarly publication can bring

- The aim of this study is the analysis of the value that Open Access brings for the special case of text mining tools.

\section{Ebola's outbreak - an emblematic case study}

- In 2015, three Liberian healthcare professionals argued that with Open Access, they would have been warned and many lives would have been saved ${ }^{3}$. In response, several authors pointed that Open Access is not enough, and that research and discovery tools were also needed ${ }^{4}$

- Revisiting this case, we study the weak signals that Open Access combined with the appropriate text mining tools could have detected.

\section{Materials and methods}

- Corpuses of open-access articles containing

"ebola" were retrieved from PubMed

- Each entry was constituted of the following: title | source | abstract | fullText | TextminedTerms

\begin{tabular}{|l|c|c|c|}
\hline & Fulltext & Abstract & TextMined \\
\hline Mean & 2377 & 116 & 16.8 \\
\hline Median & 2207 & 111 & 12 \\
\hline
\end{tabular}

Table 1. Statistical description of the corpus retrieved from pubmed

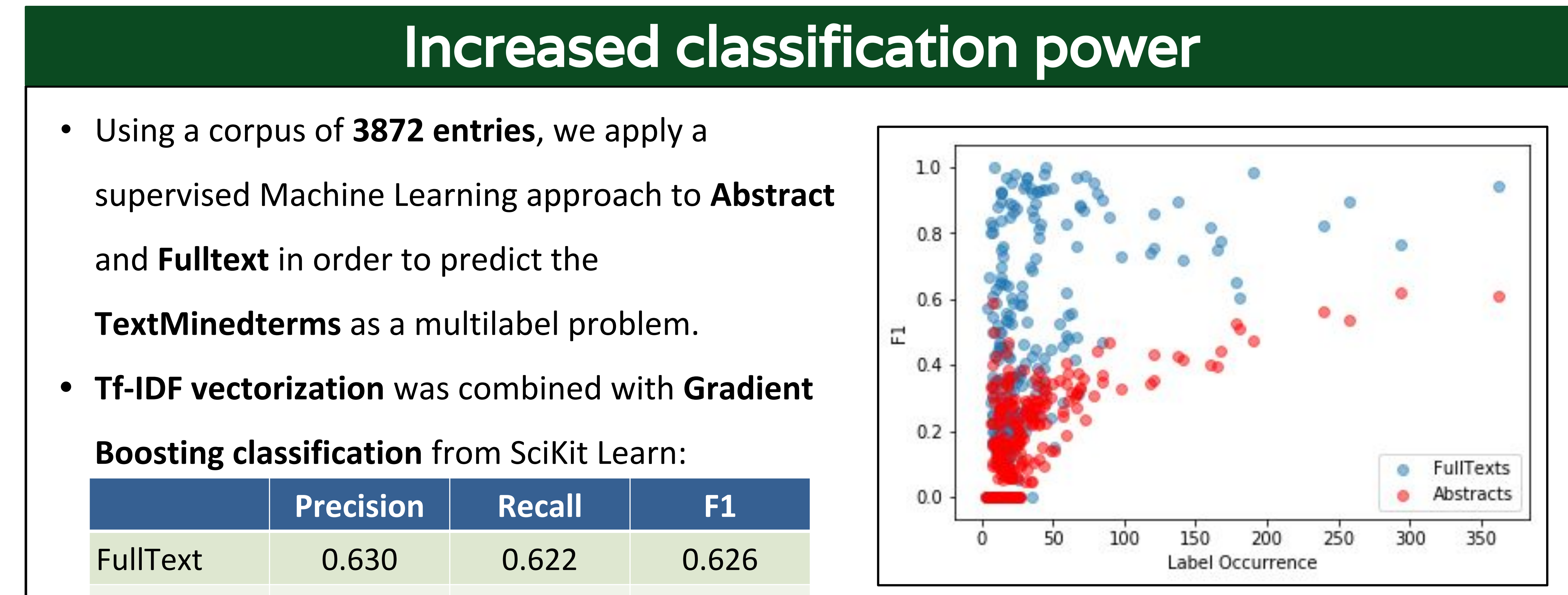

$\begin{array}{llll}\text { Abstract } & 0.324 & 0.308 & 0.316\end{array}$

Table 2. Prediction scores for Textmined Terms

\section{Chronology of Ebola in West African Countries}

- We use Elastic Search / Kibana to fine filter the presence of Liberia, Sierra Leone or Guinea in fulltext corpus and in abstract/title corpus

- A weak signal can be found before 2014 in the fulltext corpus only.

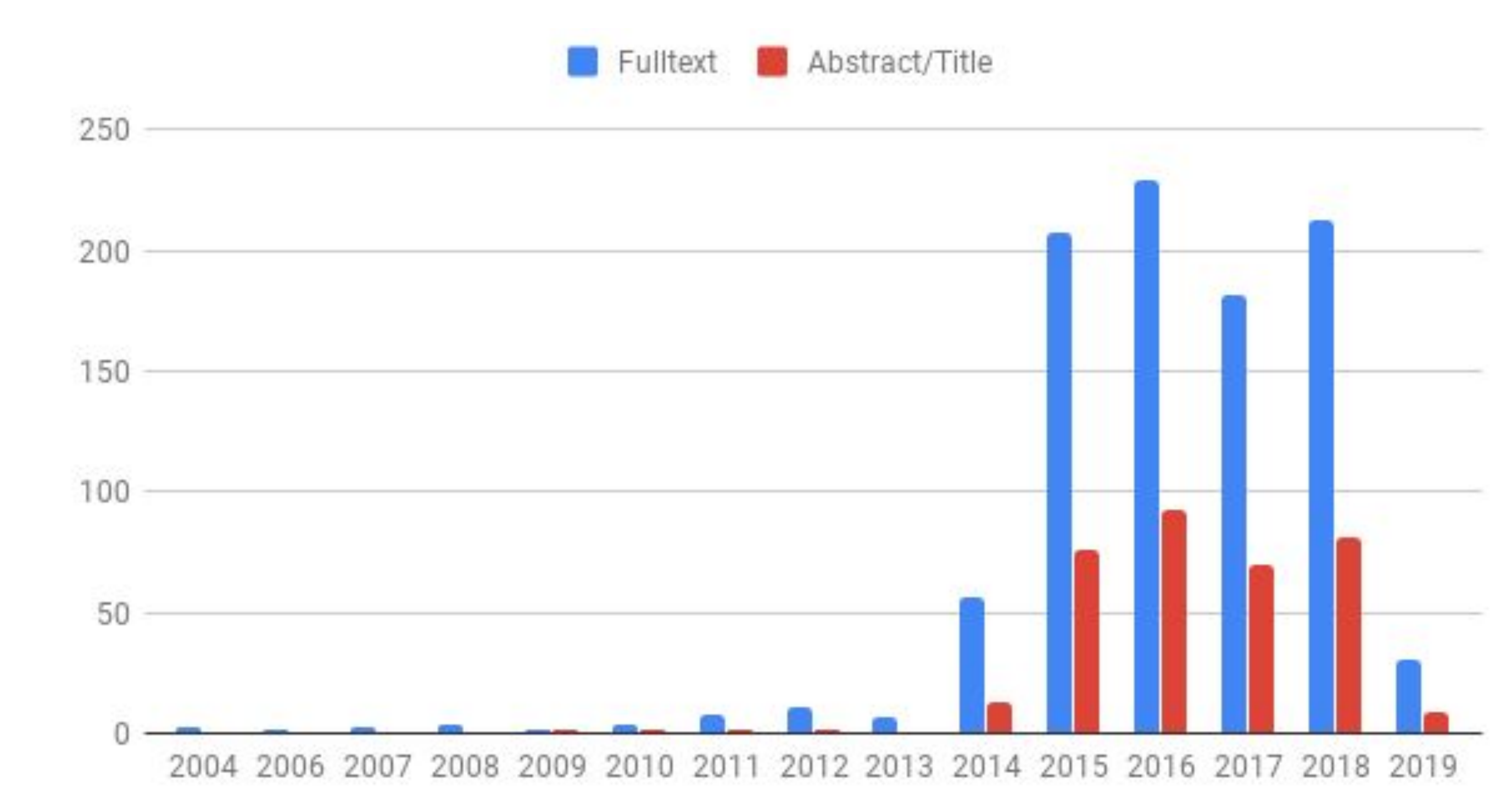

Chart 1.Fulltext vs. Abstract mentioning West African countries through years

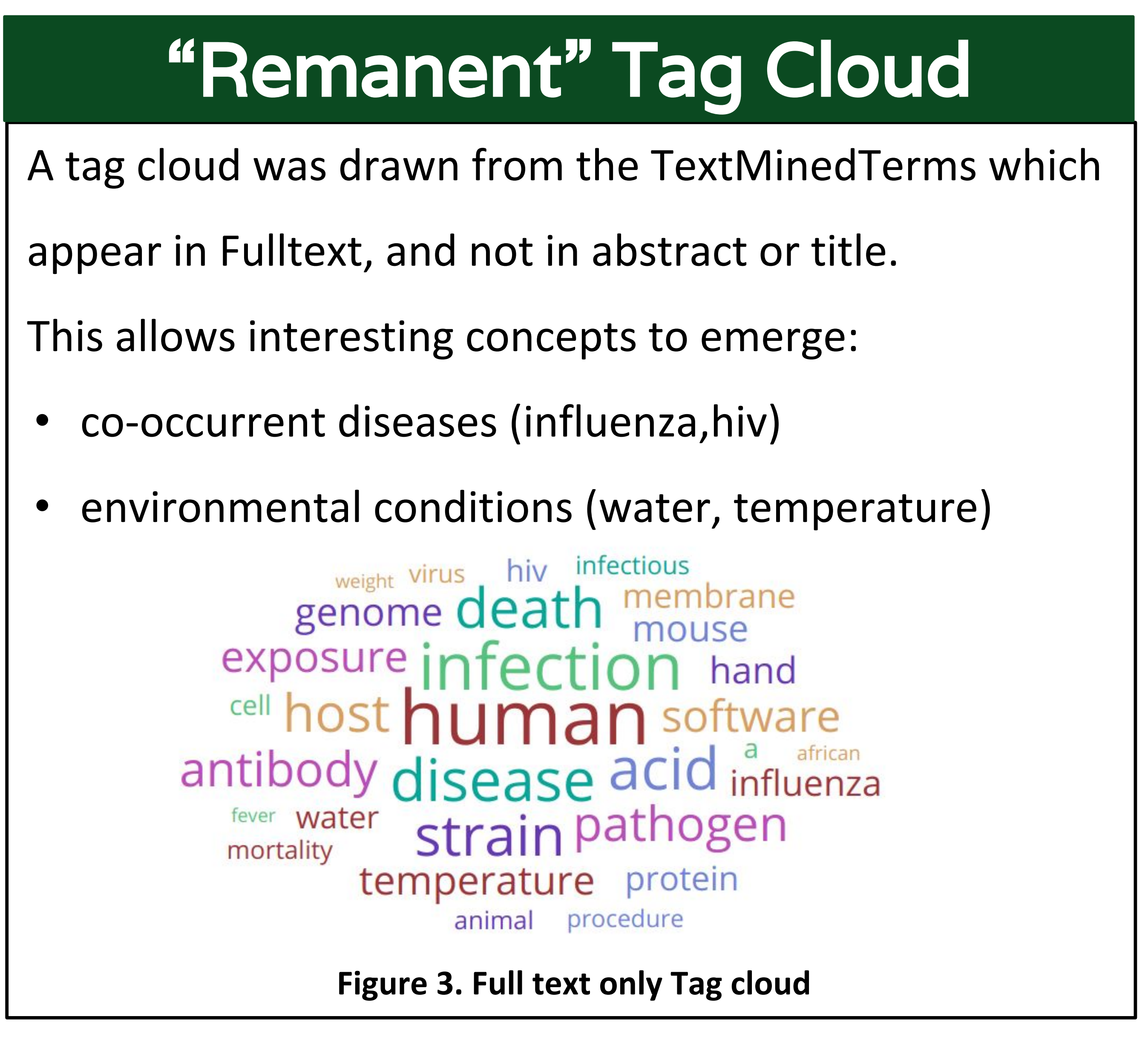

\section{Conclusions}

Based on the ebola litterature, this initial study exemplifies the extra value obtained when Textmining is applied to Fulltext rather than Abstracts only:

- A much stronger classification power is obtained: it becomes possible to predict PubMed's Textmined Terms.

- The chronology of the 2014 outbreak is observed, and an increase in the number of articles dealing with ebola in West Africa is observed before the event

- By drawing a tag cloud of the TextMined terms that appear in the FullText only, it is possible to extract concepts that it would be interesting to investigate.

A more comprehensive study will be needed to assess more quantitatively these examples, and to see how these results generalize to other case studies.

\section{Contact}

\section{OpSciDia}

www.opscidia.com

Sylvain Massip sylvain.massip@opscidia.com

0033628305920

Charles Letaillieur

charles.letaillieur@opscidia.com 0033650415099

\section{References}

1. Piwowar, H., Priem, J., Larivière, V., Alperin, J. P., Matthias, L., Norlander, B., ... Haustein,S. "The state of OA: a large-scale analysis of the prevalence and impact of Open Access articles." PeerJ, 6, e4375 (2018) https://doi.org/10.7717/peeri.4375

2. Van Noorden, R. "Open access: The true cost of science publishing." Nature, 495(7442), 426-429 (2013). https://doi.org/10.1038/495426a 3. Dahn, B., Mussah, V., \& Nutt, C. (2015, April 7). Yes, We Were Warned About Ebola. The New York Times. Retrieved from https://www.nytimes.com/2015/04/08/opinion/yes-we-were-warned-about-ebola.htm

4. Crotty, D. (2019). Access Alone Isn't Enough: Revisiting Calls for Discovery, Infrastructure, Technology, and Training. Retrieved from https://scholarlykitchen.sspnet.org/2019/01/31/access-alone-isnt-enough-revisiting-calls-for-discovery-infrastructure-technology-and-training/ 